\title{
Hematology and plasma biochemistry in rats fed with diets enriched with fatty fishes from Amazon region
}

\author{
Hematologia e bioquímica plasmática em ratos \\ alimentados com dietas enriquecidas com \\ peixes gordurosos da bacia Amazônica
}

Francisca das Chagas do Amaral SOUZA ${ }^{1}$

Wallice Paxiúba DUNCAN²

Roasany Piccolotto CARVALHO ${ }^{3}$

A B S T R A C T

\section{Objective}

Rats fed diets enriched with fatty fish from the Amazon region had Hematology and plasma biochemistry analyzed.

\section{Methods}

Forty Wistar rats were divided into four groups: control group fed a standard diet; mapará group fed a diet enriched with Hypophthalmus edentatus; matrinxã group fed a diet enriched with Brycon spp.; and tambaqui group fed a diet enriched with Colossoma macropomum. After thirty days the rats had an red blood count and plasma biochemistry.

\section{Results}

Hematocrit and hemoglobin levels were higher in rats fed tambaqui and matrinxã than in those fed the standard diet of mapará. However, mapará increased cholesterol, especially low-density lipoprotein cholesterol and high-density lipoprotein cholesterol. All fish-enriched diets reduced triacylglycerols.

\section{Conclusion}

Diets enriched with fatty fish from the Amazon region reduce triacylglycerol and increase high-density lipoprotein cholesterol, especially the diet enriched with tambaqui. Tambaqui and matrinxã affected hematocrit and hemoglobin levels, but not mapará. Further research is needed to determine the benefits of diets enriched with fatty fish from the Amazon region.

Indexing terms: Cholesterol. Diet. Parameters. Triacylglycerols.

1 Instituto Nacional de Pesquisas da Amazônia, Coordenação de Pesquisa em Sociedade Ambiente e Saúde, Laboratório de Nutrição. Av. André Araújo, 2936, Aleixo, 69060-001, Manaus, AM, Brasil. Correspondência para/Correspondence to: FCA SOUZA. E-mail: <francisca.souza@inpa.gov.br>.

${ }^{2}$ Universidade Federal do Amazonas, Instituto de Ciências Biológicas, Departamento de Morfologia. Manaus, AM, Brasil.

3 Universidade Federal do Amazonas, Instituto de Ciências Biológicas, Departamento de Fisiologia. Manaus, AM, Brasil.

Support: Fundação de Amparo à Pesquisa do Estado do Amazonas (Proccess nº 01212009 and 020/2013). 


\section{RE S U M O}

\section{Objetivo}

A hematologia e bioquímica plasmática foram avaliadas em ratos submetidos a dietas enriquecidas com peixes gordurosos da região amazônica.

\section{Métodos}

Ratos machos da linhagem Wistar foram divididos em quatro grupos: grupo-controle (dieta-padrão); grupo mapará (dietas enriquecidas com Hypophthtalmus edentatus); grupo matrinxã (dietas enriquecidas com Brycon spp.); grupo tambaqui (dietas enriquecidas com Colossoma macropomum). Os parâmetros hematológicos e as variáveis bioquímicas plasmáticas foram analisadas nos animais após 30 dias de experimentação.

\section{Resultados}

Animais alimentados com dietas enriquecidas com tambaqui e matrinxã apresentaram valores de hematócrito e concentração de hemoglobina mais elevados que aqueles alimentados com dieta padrão. Não foram observadas alterações nas variáveis hematológicas em ratos alimentados com dietas enriquecidas com mapará. Porém, os ratos desse grupo apresentaram elevados teores de colesterol total plasmáticos, principalmente de colesterol da lipoproteína de baixa densidade e colesterol da lipoproteína de alta densidade. Todos os tratamentos com dietas enriquecidas reduziram os níveis de triacilgliceróis plasmáticos.

\section{Conclusão}

Dietas enriquecidas com carne de peixes amazônicos gordurosos reduzem os teores de triacilgliceróis plasmáticos e aumentam os níveis de colesterol da lipoproteína de alta densidade, especialmente nos ratos do grupo tambaqui. Com exceção do grupo mapará, ratos alimentados com dietas enriquecidas com outras dietas enriquecidas com peixes apresentaram alterações hematológicas. Porém, fazem-se necessário mais estudos para se estabelecerem os benefícios das dietas enriquecidas com peixes gordurosos da Bacia Amazônica.

Termos de Indexação: Colesterol. Dieta. Parâmetros. Triglicerídios.

\section{N T ROD UCTIO N}

The number of studies on the health benefits of seafood has increased in the last twenty years, especially because of the importance of Polyunsaturated Fatty Acids (PUFA) in reducing cardiovascular disease risk ${ }^{1,2}$. Omega-3 fatty acids have been shown to prevent cardiovascular diseases by reducing the number of cardiac arrhythmias, lowering triglycerides, lowering blood pressure, and reducing platelet aggregation $^{3}$. However, it is not clear whether all omega-3 fatty acids reduce cardiovascular risk similarly.

Seafood is an important source of omega-3 fatty acids. Although omega-3 fatty acids are also essential for these organisms, they obtain both omega-3 and omega- 6 fatty acids. Omega-3: omega- 6 ratio is higher in saltwater fish than in freshwater fish because of their different diets ${ }^{4}$. For example, Greenlandic Inuit consume roughly $400 \mathrm{~g}$ of fish per capita per day ${ }^{5}$ and have low cardiovascular disease mortality rate $^{6}$ like the Japanese, who consume roughly $100 \mathrm{~g}$ of fish per capita per day?.

In the last years, fish intake in Brazil increased by approximately $24 \%{ }^{8}$. Yet, according to the Ministry of Fishing and Aquaculture ${ }^{8}$, Brazilians consume only $30.0 \mathrm{~g}$ of seafood per capita per day. This amount is similar to the minimum amount of $33.0 \mathrm{~g}$ per capita per day recommended by the World Health Organization $(\mathrm{WHO})$ and lower than the global consumption of $46.5 \mathrm{~g}$ per capita per day ${ }^{9}$. According to the Instituto Brasileiro de Geografia e Estatística (IBGE, Brazilian Institute of Geography and Statistics) ${ }^{10}$, fish intake in the Amazon region (104.0 g per capita per day) is higher than the Brazilian average. However, intake varies greatly by location: in the high Solimões River area, per capita intake reaches $800.0 \mathrm{~g} /$ day $^{11}$, while in Manaus' metropolitan area, the mean per capita intake is $92.0 \mathrm{~g} /$ day $^{12}$. This clearly shows that fish 
is one of the most important and intensely harvested resources in the Amazon region.

The approximate number of freshwater fish species in the Amazon region is 2,500, representing $30 \%$ of the total number of freshwater fish on the planet ${ }^{13}$. Freshwater fish have high levels of C-16 and C-18 and low levels of C-20 and C-22 PUFA (among them Eicosapentaenoic [EPA] and Docosahexaenoic [DHA]) when compared with saltwater fish ${ }^{14}$, but according to many studies, the levels of EPA and DHA are still very high in freshwater fish. Inhamuns \& Franco ${ }^{15}$ found that the catfish mapará (Hypophthalmus spp.) has high levels of EPA and DHA in their muscles during the Amazon basin flood stage, when more food is available. Mapará muscle contains more PUFA than tambaqui (Colossoma macropomum) and matrinxã (Brycon spp.) muscles. Proportionally, tambaqui has more Saturated Fatty Acids (SFA) than Monounsaturated Fatty Acids (MUFA) and PUFA. Although mapará is classified as a fatty fish, most of its fatty acids are PUFA and MUFA instead of SFA ${ }^{16}$. Hence, in terms of nutrition, mapará is an excellent source of MUFA and PUFA, reducing cardiovascular risk. Additionally, these fatty acids may also reduce triacylglycerols and total cholesterol and increase High Density Lipoproteincholesterol (HDL-C).

However, there are reports that fatty foods affect blood variables ${ }^{17}$. For example, high-fat diets change blood cell-related characteristics, increase total cholesterol and Low Density Lipoprotein-cholesterol (LDL-c), and decrease HDL-c. On the other hand, low levels of fatty acids increase blood viscosity and the risk of atherosclerosis ${ }^{18}$. Blood viscosity increases when hematocrit, number of circulating erythrocytes, or cell volume increases. Thus, diets enriched with fish containing highlevels of SFA, such as tambaqui, may have negative effects.

The study objective was to analyze the effects of fatty fish from the Amazon region on the blood cell count and lipids of male Wistar rats.

\section{METHODS}

Forty male Wistar rats (Rattusnorvegicus) aged about thirty days and weighing $240 \mathrm{~g} \pm 0.60$ were obtained from the Universidade Federal do Amazonas (UFAM) central vivarium. All animals were fed the standard diet for three days. They were then divided into four groups of ten animals each, kept in individual cages maintained under a 12/12-hour light-dark cycle and controlled temperature, andgiven free access to water and the study diet. This study was approved by the Animal Research Ethics Committee of the UFAM under Protocol CEUA- 014/12.

\section{Diet preparation}

The diets were prepared as recommended by Souza et al. ${ }^{19}$. In summary, the fish muscle was deboned mechanically (Baader 694 Bone Separator) and immediately frozen to $-30^{\circ} \mathrm{C}$. The bulk of the experimental diets wasthe commercial chow Nuvilab CR-1 (Nuvilab ${ }^{\circledR}$ Nutrientes Ltda, Curitiba, PR). The diets based on Amazon fish consisted of commercial chow $(72.5 \%)$, casein (12.5\%), and mechanically deboned and minced muscle (15.0\%) of the following species: mapará (Hypophthtalmus edentatus), matrinxã (Brycon spp.), and tambaqui (Colossomama cropomum). All components were ground and mixed. The final composition of each experimental diet was $22.0 \%$ proteins, $10.5 \%$ lipids, $40.0 \%$ carbohydrates, and $16.0 \%$ fibers.

\section{Red blood count}

At the end of the experiment, the animals were anesthetized with Ketamine ${ }^{\circledR}(0.15 \mathrm{~mL} / 100$ $\mathrm{g}$ of body weight) and the painkiller Rompun ${ }^{\circledR}$ (0.015 mL $100 \mathrm{~g}$ of body weight) tocollect blood by cardiac puncture. Red blood cells were counted as recommended by Kampen \& Zijlstra ${ }^{20}$. Hemoglobin level was estimated by the cyanmethemoglobin method as $([\mathrm{Hb} \mathrm{g} / \mathrm{dL}]=$ Absorbance $(540 \mathrm{~nm}) \times 0.146$ (correction factor) 
x 200 (blood sample dilution). Hematocrit (Ht\%) was determined by collecting blood in microhematocrit heparinized tubes and centrifuged at $1200 \mathrm{rpm}$ for five minutes. The reading was done in a standard card. Circulating erythrocytes (x10\%) $\mathrm{mm}^{3}$ ) were counted after diluting the blood in saline (1:200 v:v). The erythrocytes were counted directly under 400x magnification using the chamber Neubauer. The corpuscular constants were estimated as follows: Mean Corpuscular Volume $(\mathrm{MCV}=(\mathrm{Ht} / \mathrm{RBC}) \times 10)$ in $\mu^{3}{ }^{3}$; Mean Corpuscular Hemoglobin $(\mathrm{MCH}=([\mathrm{Hb}] / \mathrm{RBC}) \times 10)$ in picograms; and Mean Corpuscular Hemoglobin Concentration $(\mathrm{MCHC}=([\mathrm{Hb}] / \mathrm{Ht}) \times 100)$ in \%.

\section{Lipoprotein panel}

The plasma was separated by centrifugation at 7,500 rpm for two minutes to determine glucose, total protein, triacylglycerol, total cholesterol, and HDL-c levels. Glucose was determined by the colorimetric assay kit Glucox 500 Doles $^{\circledR}$. This assay uses the enzyme glucose oxidase and a spectrophotometer to measure absorbance at $510 \mathrm{~nm}$. Total protein was determined by the Bradford protein assay, which uses the dye Coomassie Brilliant Blue G-250 and measures absorbance at $595 \mathrm{~nm}$, proportionally reflecting protein concentration. Triacylglycerols were determined by the colorimetric assay kit Triglycerides 120 Doles $^{\circledR}$. This method uses the enzyme glycerol-3-phosphate oxidase and measures absorbance at $510 \mathrm{~nm}$. Total cholesterol was determined by the colorimetric assay kit Colesterol 250 Doles $^{\circledR}$, which uses the enzyme cholesterol oxidase and measures absorbance at $510 \mathrm{~nm}$. HDL-c was determined by the colorimetric assay kit Colesterol-HDL from Renylab ${ }^{\circledR}$, which uses phosphotungstic acid and magnesium chloride, and measures absorbance at $510 \mathrm{~nm}$. Very Low Density Lipoprotein-cholesterol (VLDL-c) and LDL-c were given by Friedwald's equation: VLDL-C $=($ triacylglycerols $/ 5)$ and LDL-C $=$ total cholesterol - (HDL-C + VLDL-c).

\section{Statistical analyses}

Blood variables are expressed as mean \pm standard deviation. The Kolmogorov-Smirnov test assessed whether each variable had a normal distribution. No data group was transformed. The treatments (diets enriched with mapará, matrinxã, and tambaqui) were compared with the control group (standard diet) by one-factor Analysis of Variance (Anova) followed by Dunnett's post hoc test. The significance level was set at $5 \%$ for all tests $(p<0.05)$. The data was treated by the software SigmaPlot (Systat Software, Inc).

\section{RES U LTS}

After the 30-day experimental period, rats fed tambaqui- and matrinxã-enriched diets had higher Hematocrit $(\mathrm{Ht})$ and Hemoglobin Levels $(\mathrm{Hb})$ than those fed the standard diet (Figure 1) $(p<0.05)$. Moreover, the total number of circulating erythrocytes increased significantly in animals fed the tambaqui-enriched diet $(p<0.05)$. Matrinxã significantly increased erythrocyte volume and decreased $(p<0.05)$ mean corpuscular hemoglobin concentration (Figure 2). Mapará caused no RBC-related changes.

Figure 3 shows the glucose, total protein, and triacylglycerol data. Rats fed the tambaquienriched diet had significantly lower blood glucose than those fed the standard diet $(p<0.05)$. Blood glucose was not affected by the other diets. None of the experimental groups experienced changes in total protein levels, but all experimental groups experienced a reduction in triacylglycerol and VLDL-c levels $(p<0.05)$. However, total cholesterol increased in rats fed the maparáenriched diet. Their HDL-C and LDL-C were both high (Figure 4). The only experimental diet that increased HDL-c was the tambaqui-enriched diet, but it did not affect LDL-c or total cholesterol.

\section{DISCUSSION}

High low density lipoprotein-cholesterol and low HDL-c increase blood viscosity, and this 

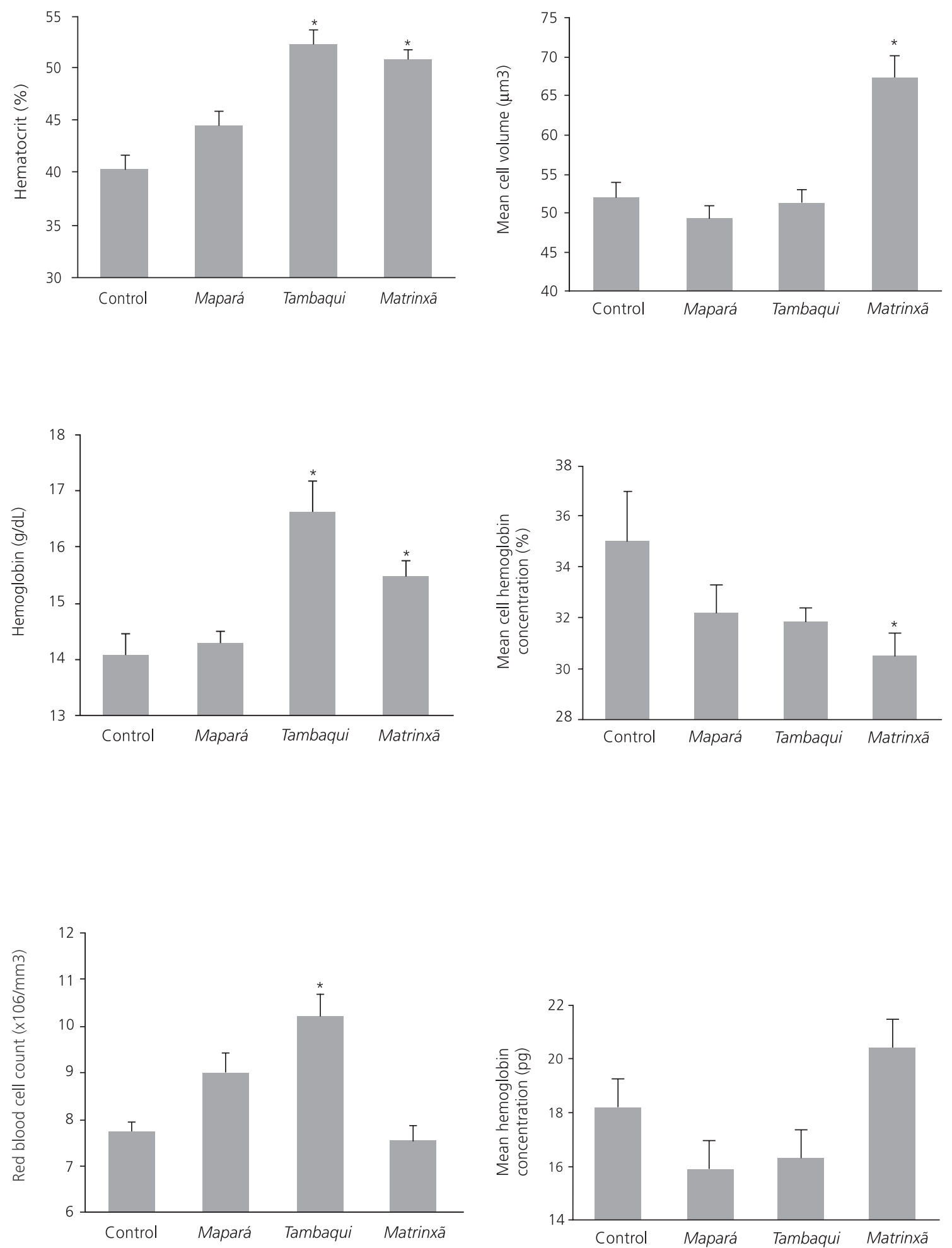

Figure 1. Hematocrit, hemoglobin level, and number of circulating erythrocytes of Wistar rats fed diets enriched with Amazon region fatty fish.

Note: *Indicates a significant difference from the control group fed the standard diet $(p<0.05)$.

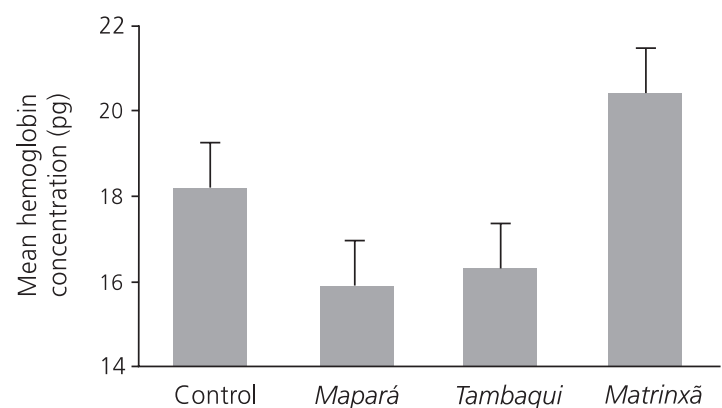

Figure 2. Red blood cell indices, cell volume, mean corpuscular hemoglobin concentration, and Mean Corpuscular Hemoglobin $(\mathrm{MCH})$ in Wistar rats fed diets enriched with Amazon region fatty fish.

Note: *Indicates a significant difference from the control group fed the standard diet $(p<0.05)$. 

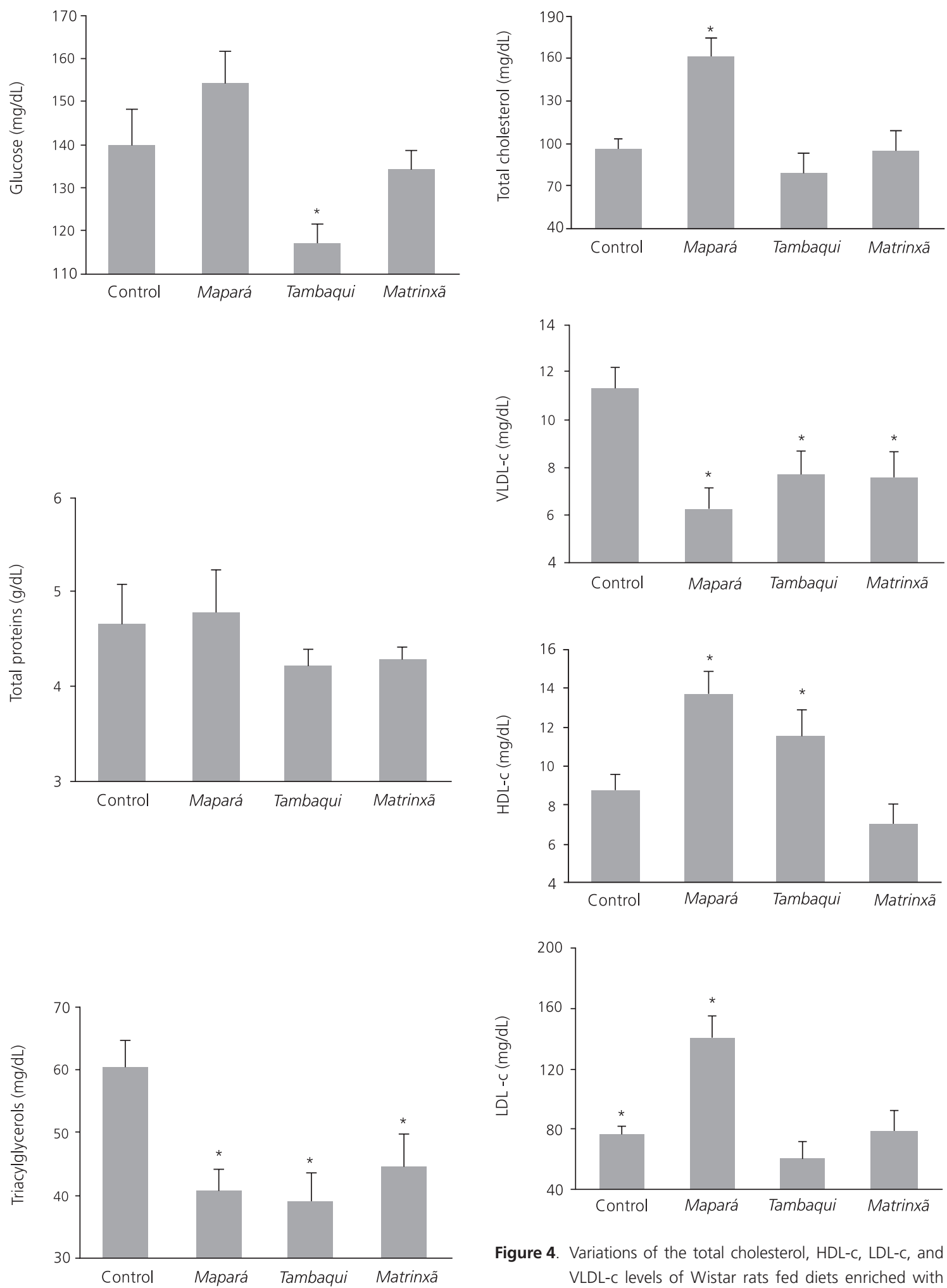

Figure 4. Variations of the total cholesterol, HDL-C, LDL-C, and VLDL-c levels of Wistar rats fed diets enriched with Amazon region fatty fish.

Figure 3. Glucose, triacylglycerols, and total proteins of rats fed diets enriched with Amazon region fatty fish.

Note: *Indicates a significant difference from the control group fed the standard diet $(p<0.05)$.

Note: *Indicates a significant difference from the control group fed the standard diet $(p<0.05)$.

HDL: High Density Lipoprotein-cholesterol; LDL: Low Density Lipoproteincholesterol; VLDL: Very Low Density Lipoprotein-cholesterol. 
abnormal rheological property increases the risk of atherogenesis ${ }^{21,22}$. The increase in the number and volume of circulating red blood cells affect $\mathrm{Ht}$ and blood viscosity ${ }^{23}$. Rats fed the tambaquiand matrinxã-enriched diets experienced changes in $\mathrm{Ht}$ and hemoglobin levels but the associated physiological mechanisms are distinct: in the matrinxã group, high $\mathrm{Ht}$ occurred because of an increase in the number of circulating erythrocytes, while in the tambaqui group, high $\mathrm{Ht}$ was due to erythrocyte swelling, that is, the cells increased in volume. An increase in cell volume causes dilution of erythrocyte hemoglobin (low MCHC). Erythrocyte volume may increase due to changes in osmoregulation, which include fewer plasma solutes ${ }^{24}$ and failure in the erythrocyte membrane ion transport system ${ }^{25}$. The mechanism by which high-lipid diets affect blood variables has not yet been clarified. Therefore, the secondary effects of these diets should be investigated routinely by $\mathrm{RBC}$ because many studies have found that high triacylglycerol levels increase the volume of circulating erythrocytes ${ }^{26}$.

Interestingly, diets enriched with minced Amazon fish reduced triacylglycerol and VLDL-C levels significantly, possibly due to the high levels of EPA and DHA in these fish ${ }^{27}$. Additionally, fish oil has been shown to reduce the total cholesterol, LDL-C, and triacylglycerol levels of women aged 51 to 71 years ${ }^{24}$. Suprijana et al. ${ }^{28}$ too found that fish oil reduced rats' triacylglycerol, total cholesterol, and cholesterol fractions, corroborated by Kim et al. ${ }^{29}$. Dyslipidemic patients treated with fish oil rich in omega- 6 fatty acids experienced a reduction in total cholesterol, LDL-C, VLDL- $\mathrm{C}^{30}$ and triacylglycerols, and an increase in $\mathrm{HDL}-\mathrm{C}^{31}$. Another nutritional benefit at least in murine models is that Amazon fish-enriched diets increase $\mathrm{HDL}-\mathrm{c}$, especially if the fish is tambaqui or mapará. However, the minced mapará-enriched diet increased LDL-c. MUFA levels in tambaqui and mapará are $28.2 \%$ and $35.3 \%$, respectively, and PUFA levels are $10.1 \%$ and $23.9 \%$, respectively ${ }^{16}$. Although SFA in tambaqui is high $(68.7 \%$ of the total fat content), it did not affect rats' LDL-C. Studies using labeled VLDL-c apoB-100 found that this fraction is the precursor of $L D L-C^{32}$. This lipid metabolism pathway suggests that higher LDL-C synthesis lowered the VLDL-c of rats fed minced mapará.

In summary, the study data suggest that in murine models: (1) diets enriched with Amazon fish reduce triacylglycerol levels; (2) this result is corroborated by low VLDL levels; (3) mapará is considered a fatty fish, so diets enriched with minced mapará increase total cholesterol, especially LDL-c and HDL-c; (4) tambaqui was the only fish that increased HDL-C; (5) while matrinxãand tambaqui-enriched diets affect RBC counts, the minced mapará-enriched diet increased total cholesterol, LDL-C (85\%), and HDL-C (56\%) compared with the standard diet; (6) minced tambaqui- and matrinxã-enriched diets change blood variables. However, more studies are needed to understand the physiological effects of diets enriched with fatty fish from the Amazon region.

\section{ACKNOWLEDGMENTS}

The authors thank Fundação de Amparo à Pesquisa do Estado do Amazonas for sponsoring Francisca das Chagas do Amaral Souza (process 062.01725.2014/FAPEAM). We thank Instituto Nacional de Pesquisas da Amazônia for their help and for sponsoring the study.

\section{CONTRIBUTORS}

FCA SOUZA has contributed in planned and carried out all experiments. Processed the samples and wrote and reviewed the final version of the manuscript. WP DUNCAN has contributed in conducted the complete blood counts and lipoprotein panels. Performed the statistical analyses and graphed the results. Reviewed the final version of the manuscript. RP CARVALHO has contributed in planned and coordinated the experiments. Coordinated the laboratory tests and spreadsheet development. Wrote and reviewed all versions of the manuscript. 


\section{REFERE N CES}

1. Wang YJ, Miller LA, Perren M, Addis PB. Omega-3 fatty acids in Lake Superior fish. J Food Sci. 1990; 55(1):71-3. doi: 10.1111/j.1365-2621.1990.tb0 6018.x

2. Sartori AGO, Amancio RD. Pescado: importância nutricional e consumo no Brasil. Segur Aliment Nutr. 2012; 19(2):83-93.

3. Nair SS, Leitch JW, Falconer J, Garg ML. Prevention of cardiac arrhythmia by dietary $(n-3)$ polyunsaturated fatty acids and their mechanism of action. J Nutr. 1997; 127(2):383-93.

4. Souza SMG, Anido RJV, Tognon FC. Ácidos graxos Ômega-3 e Ômega-6 na nutrição de peixes: fontes e relações. Rev Ciênc Agroveter. 2007; 6(1):63-71.

5. Stone NJ. Fish consumption, fish oil, lipids, and coronary heart disease. Circulation. 1996; 94:2337-40. doi: 10.1161/01.CIR.94.9.2337

6. Bang HO, Dyerberg J, Sinclair HM. The composition of the Eskimo food in Northwestern Greenland. Am J Clin Nutr. 1980; 33(12):2657-61.

7. Wakai K, Ito Y, Kojima M, Tokudome S, Ozasa K, Inaba $Y$, et al. Intake frequency of fish and serum levels of long-chain n-3 fatty acids: A cross-sectional study within the Japan Collaborative Cohort Study. J Epidemiol. 2005; 15(6):211-8. doi: 10.2188/jea.1 5.211

8. Brasil. Ministério da Agricultura, Pecuária e Abastecimento. Balança comercial do agronegócio. Brasília: Ministério da Agricultura, Pecuária e Abastecimento; 2012.

9. Technical Guidance. Update of the criteria used in the assessment of bacterial resistance to antibiotics of human or veterinary importance. Prepared by the panel on additives and products or substances used in animal feeds. EFSA J. 2008; 732:1-15.

10. Instituto Brasileiro de Geografia e Estatística. Pesquisa de orçamentos familiares 2008-2009: análise do consumo alimentar pessoal no Brasil. Rio de Janeiro: IBGE; 2011.

11. Isaac VJ, Almeida MC. El consumo de pescado en la Amazonía Brasileña. COPESCAALC Doc Ocacional. 2011; (13):1-43.

12. Gandra AL. O mercado de pescado da região metropolitana de Manaus. Montevidéu: Infopesca; 2010. O mercado de pescado nas grandes cidades latino-americanas.

13. Val AL, Almeida-Val VMF. Fishes of the Amazon and their environment- physiological and biochemical aspects. New York: Springer; 1995. Zoophysiology Series, v.32.

14. Philibert A, Fillion M, DeGuirre JR, Weiler HA, Passos CJS, Lemire $M$, et al. Plasma phospholipid omega-
3 fatty acids and freshwater fish consumption in the Brazilian Amazon. Food Nutrition Scienc. 2013; 4(9A):137-49. doi: 10.4236/fns.2013.49A1021

15. Inhamuns AJ, Franco MRB. EPA and DHA quantification in two species of freshwater fish from Central Amazonia. Food Chem. 2008; 107(2):587-91. doi: 10.1016/j.foodchem.2007.07.032

16. Sousa RV. Óleo de tambaqui (Colossomamacropomum, Cuvier): características nutricionais e ação no metabolismo de lipídios em ratos hipercolesterolêmicos [mestrado]. Belo Horizonte: Universidade Federal de Minas Gerais; 1996.

17. Abdelhalim MAK, Alhadlaq H. Effects of cholesterol feeding periods on blood haematology and biochemistry of rabbits. Int J Bio Chem. 2008; 2(2):49-53. doi: 10.3923/ijbc.2008.49.53

18. Sloop GD, Garber DW. The effects of low-density lipoprotein and high-density lipoprotein on blood viscosity correlate with their association with risk of atherosclerosis in humans. Clin Sci. 1997; 92(5):473-9.

19. Souza FCA, Garcia NP, Sales RSA, Aguiar JPL, Duncan WLP, Carvalho RP. Effect of fatty Amazon fish consumption on lipid metabolism. Rev Nutr. 2014; 27(1):97-105. doi: 10.1590/1415-52732014 000100009

20. Kampen EJ, Zijlstra WG. Erythrocytometric methods and their standardization. Clin Chimica Act. 1964; 6:538-42.

21. Toz H, Duman S, Altunel E, Sezis M, Ozbek S, Ozkahya $M$, et al. Intima media thickness as a predictor of atherosclerosis in renal transplantation. Transplant Proc. 2004; 36(1):156-8. doi: 10.1016/ j.transproceed.2003.11.058

22. Thomas DS, Robert SR. Low high density lipoprotein levels are associated with an elevated blood viscosity. Atherosclerosis. 1999; 146(1):161-5.

23. Lee $H B$, Blaufox MD. Blood volume in the rat. J Nucl Med. 1985; 25(1):72-6.

24. Clark MR, Mohandas N, Shohet B, Hoesch RM, Rossi MR. Osmotic gradient ektacytometry: Comprehensive characterization of red cell volume and surface maintenance. Blood J. 1983; 61(5):899-910.

25. Lang F, Busch GL, Ritter M, Völkl H, Waldegger S, Gulbins $E$, et al. Functional significance of cell volume regulatory mechanisms. Physiol Rev. 1998; 78(1):247-306.

26. Bunyaratvej P, Komindr S, Wisedpanichkij R. Different reticulocyte volume in diabetes Mellitus patients with and without hypercholesterolemia and/or hypertriglyceridemia. J Med Assoc. 2000; 83(7):790-6. 
27. Moreira AB, Visentainer JV, Souza NE, Matsushita M. Fatty acids profile and cholesterol contents of three Brazilian Brycon freshwater fishes. J Food Comp Anal. 2001; 14(6):565-74.

28. Suprijana O, Terpstra AHM, Van Lith HA, Van Tol A, Lemmens AG, Geelhoed-Mieras MM, et al. Plasma lipids and apolipoproteins in rats fed diets with type of fat (fish oil versus corn oil) and fiber (pectin versus cellulose) as variables. Nutr Res. 1997; 17(7):1187-97.

29. Kim HK, Choi S, Choi H. Suppression of hepatic fatty acid synthase by feeding a-linolenic acid rich perilla oil lowers plasma triacylglycerol level in rats. J Nutr Biochem. 2004; 15(8):485-92.
30. Charman A, Muriithi EW, Milne E. Wheatley DJ, Armstrong RA, Belcher PR. Fish oil before cardiac surgery: Neutrophil activation is unaffected but myocardial damage is moderated. Prostag, Leukotr Ess. 2005; 72(4):257-65.

31. Singer P. Fluvastantinplus fish oil are more effective on cardiovascular risk factors than fluvastatin alone. Prostag Leukotr Ess. 2005; 72(5):379-80.

32. Murray RK, Bender DA, Botham KM, Kennelly PJ, Rodwell VW, Well PA. Harper's illustrated Biochemistry. 26 ${ }^{\text {th }}$ ed. Toronto: McGraw-Hill; 2003.

Received on: 12/12/2013

Final version on: 7/15/2014

Approved on: 8/5/2014 
